\title{
Legal Pluralism as a Theory for the Challenges on Environmental Health*
}

Received: February 3rd 2018 • Approved: July 30th 2018

https://doi.org/10.22395/ojum.v18n36a10

\section{Ronald Ralf Becerra"}

\begin{abstract}
This paper intends to justify the theory of legal pluralism for studying environmental health issues. The positive law approach has made some headway, although some areas of environmental health seem to be incipient. Hard law has encountered difficulties to succeed in enforcing industrial pollution or water contamination. Furthermore, national jurisdictions are prone to support particular economic interests. This conundrum of legal positivism encourages challenging it with the theory of pluralism. It is found that the latter might allow deliberation and active participation of non-state actors within environmental health. It is also discussed that the plurality of law allows certain flexibility due to its little hierarchization, the lack of theoretical rules and the relaxation of state sovereignty.

Keywords: legal positivism; legal pluralism; environmental health; interlegality.
\end{abstract}

This paper stems from a research project that is currently under way (the autor is its senior researcher), called "La responsabilidad jurídica empresarial en la protección de la salud del medio ambiente. El derecho internacional y el derecho colombiano". The project was endorsed and funded by the Economic Law and State Research Group (C Rank, Colciencias) at the Faculty of Law of Corporación Universitaria Republicana.

* BA in Law, Universidad Libre (Barranquilla, Colombia). MA Degree in International Trade Law, London Metropolitan University. Lecturer-researcher, Corporación Universidad Republicana, Bogotá, Colombia. E mail: rbecerra@urepublicana.edu.co. Orcid: https://orcid.org/0000-0002-2691-8851. 


\title{
Pluralismo jurídico como teoría para los desafíos en salud ambiental
}

\begin{abstract}
RESUMEN
Este artículo pretende justificar la teoría del pluralismo jurídico para el estudio de la problemática de la salud ambiental. Aunque el derecho positivo ha presentado ciertos avances, existen algunas áreas de la salud ambiental que parecen encontrarse en estado incipiente. Las normas estatales han manifestado dificultades para lograr su cumplimiento en materia de contaminación industrial o del agua, a lo cual se suma el hecho de que las jurisdicciones nacionales tienden a privilegiar intereses económicos particulares. Este problema del positivismo fomenta su confrontación con la teoría del pluralismo legal, y se encuentra que dicha aproximación teórica permite la deliberación y la participación activa de actores no estatales en la esfera de la salud ambiental. Este documento también pone en discusión que un enfoque pluralista del derecho podría otorgar cierta flexibilidad debido a la poca jerarquización, la falta de reglas teóricas y la relajación del principio de la soberanía estatal.
\end{abstract}

Palabras clave: derecho positivo; pluralismo jurídico; salud ambiental; interlegalidad.

\section{Pluralismo legal como teoria para os desafios em saúde ambiental}

\section{RESUMO}

Este artigo pretende justificar a teoria do pluralismo jurídico para o estudo da problemática da saúde ambiental. Embora o direito positivo tenha apresentado certos avanços, existem algumas áreas da saúde ambiental que se encontram em um estado incipiente. As normas estatais manifestaram dificuldades para conseguir seu cumprimento em matéria de contaminação industrial ou da água, ao que se soma o fato de que as jurisdições nacionais tendem a privilegiar interesses econômicos particulares. Esse problema do positivismo fomenta seu confronto com a teoria do pluralismo legal e nota-se que tal aproximação teórica permite a deliberação e a participação ativa de agentes não estatais na esfera da saúde ambiental. Este documento também coloca em discussão que uma abordagem pluralista do direito poderia outorgar certa flexibilidade devido à pouca hierarquização, à falta de regras teóricas e ao abrandamento do princípio da soberania estatal.

Palavras-chave: direito positivo; pluralismo jurídico; saúde ambiental; interlegalidade. 


\section{INTRODUCTION}

The World Economic Forum revealed pervasive and deleterious effects on the situation of environmental health worldwide. Meanwhile, the Lancet Commission on Pollution and Health identified pollution as the largest environmental cause of disease and death (Gawel, 2017). This is partly because we are exposed to pollution every single day: For example, cycling to work leads people to breathe the fumes, as well as drinking water to intake microplastics (Gawel, 2017). Nonetheless, the concept of environmental health is quite broad, and thereby includes a wide range of issues. According to Moeller (2011),

Environmental Health is the segment of public health that is concerned with assessing, understanding, and controlling the impacts of people on their environment and the impacts of the environment on them. Even so, this field is defined more by the problems it faces than by the approach it uses. The problems include the treatment and disposal of liquid and airborne wastes, the elimination or reduction of stresses in the workplace, the purification of drinking-water supplies, the provision of food supplies that are adequate and safe, and the development and application of measures to protect hospital and medical workers from being infected with diseases (...). (Moeller, 2011, p. 8)

Despite the difficulties to gauge a clear impact of the environmental health problem, statistics pictured a staggering situation. According to a new study by researchers of the Orb and the School of Public Health at the University of Minnesota in 2017, some $83 \%$ of tap water samples, collected from a dozen countries in five continents, tested positive for microplastics (Morrison \& Tyree, 2017). Furthermore, diseases caused by pollution determined an estimated 9 million premature deaths in 2015. This represents $16 \%$ of all deaths worldwide, and 15 times more than the amount of deaths from all wars and other forms of violence. Environmental health issues like pollution are costly since pollution-related diseases cause a reduction of the GDP by up to $2 \%$ per year in middle-income and low-income countries (Landringan et al., 2017).

International positive law has developed different frameworks to grapple with environmental health issues. International lawyers and activists might rely on the law of state responsibility to solve legal issues of international environmental health. This means that international agreements operate mainly in state-to-state negotiations as a common source of dispute resolution. Consequently, national courts and tribunals have usually played a minor role in environmental international issues (Mc Arthur, 2013). On the contrary, domestic law solves environmental issues based on accepted judicial structure (Mc Arthur, 2013). Nonetheless, decisions of domestic courts are usually inadequate since those judgments ignored the international scope of environmental harm. Furthermore, national courts often privilege national economic interests (Lewis, 
as cited in Maguire, Lewis, \& Sampford, 2013). In brief, the enforcement of international and domestic environmental rights remains an issue of concern for environmental lawyers and activists (Mc Arthur, 2013; Taylor, 2008).

Nevertheless, great headway has been made in many jurisdictions. In Colombia, the Constitutional Court declared the Atrato River as a legal entity. Consequently, that same Court ordered the Colombian government to exert legal representation along with ethnic communities (Sentencia T-622/ 2016). Moreover, New Zealand was the first country in the world to recognize such legal right to the Whanganui River in 2012. This was the result of negotiations between the New Zealand government and the Maori people (Hsiao, 2012). Similar advancements have taken place in Ecuador, India, Bolivia, and some other jurisdictions (Kothari, Margil \& Bajpai, 2017).

However, this paper proposes legal pluralism as an alternative path to deal with environmental health issues. Teubner (1997) recognizes that several realms intend and compete to control global environmental issues. These systems are far away from national law structures. These are major players in the international trade market such as financial institutions, NGOs or multinational companies (Pérez, 2004). Also, indigenous communities in the western world have spawned their own body of rules to protect the environment. Thus, legal pluralism has been an alternative for environmental health insofar as it allows permeability. This means that those parallel norms might transcend international and national laws. The dominant State-Nation is hence losing power to determine environmental decisions (Mol, 2016). Rather, indigenous communities, environmental activists or private institutions might provide and compete in regulation (Richardson, 2008).

In consideration of the foregoing, we understand legal pluralism as the coexistence of several legal realms within the same social field (Merry, 1988). Our conception is broad and includes many other normative settings in the society. On the other hand, our view of positivism entails a kelsenian approach. A norm to exist must be enacted by an authority recognized within a legal order; otherwise, such norm might not be validated or considered as 'pure' (Sievers, 2015).

Taking into account such tension between positivism and legal pluralism, this article proposes to justify the theory of legal pluralism as a tool to deal with environmental health challenges. Consequently, we will arrive to a sort of comparative criteria grid in order to orientate such a task.

This document relies on literature from recognized authors, as well as international and national frameworks and jurisprudence, to support this hypothesis. Firstly, the article presents an overview for the different approaches of legal pluralism theory. 
Afterwards, the second section outlines the major issues of environmental health, and how positive law has dealt with them. Finally, the third part proposes three points to compare positive law and legal pluralism approaches in grappling with environmental health. However, these three aspects are not comprehensive and might have some limitations, as this research is purely theoretical.

\section{UNDERSTANDING LEGAL PLURALISM}

Legal pluralism supports two basic tenets: firstly, that there is more than one system of law in the same territory, and secondly, that the law does not only stem from the State, but non-state rules serve also a source of law (Hertogh, 2007).

Under this perspective, we might commence by explaining that legal pluralism entails two positions among the scholars: the weak and the strong pluralism. The first explanations of Griffiths might lead to grasp the strong view of legal pluralism. Afterwards, we will briefly describe the weak view of legal pluralism.

To understand the strong view of legal pluralism, we should know what is not legal pluralism a strong sense. This task was well developed by John Griffiths in his landmark article, in 1986. In his endeavour to describe the concept of legal pluralism, Griffiths studied different authors and their right choices and pitfalls to define it. For example, he referred to M. B. Hooker, who defines legal pluralism as "the existence of multiple systems of legal obligation [...] within the confines of the state (Griffiths, 1986, p. 9)". Nonetheless, Griffiths did not agree with Hooker, as the latter defended the superiority of state law. Hooker believed on the possibility for state law to abolish indigenous systems (Griffiths, 1986).

Legal pluralism is also different from legal diversity. When there is no general legal order in local, provincial or state jurisdictions, some rules will be developed in local levels. This is a diversity of rules within the same legal order (Griffiths, 1986). According to Griffiths (1986), legal pluralism refers to "the presence in a social field of more than one legal order (p. 1)". We cannot confuse the application of different rules in the sense of jurisdiction in the same legal order as a way of legal pluralism. If recognition exists for just one legal order, there is no legal pluralism in depth. As Griffiths (1986) indicated, legal pluralism "was not an aspect of geographical areas (p. 12)".

One might think that different rules for identical situations are manifestations of legal pluralism in a strong sense. This was the position of Vanderlinden (1989). However, it can be a bewildering task to demonstrate that this fits into the concept of strong legal pluralism. If we observe social security systems, which normally have different codes or benefits for different people, they are not examples of this kind of 
legal pluralism (Rouland, 1994). Instead, social security systems are part of one legal order, which very often stems from State policy. Then, a similar situation like a surgery or basic medical attention can be different if you are a member of the army, public government, a teacher, an unemployed person, and etcetera.

Legal pluralism is not an exclusive realm for those groups part of hierarchical agreements. In legal pluralism, there is no meta-rule imposed on the other sub-groups. Guilds, churches, and even gangs are included in the broad notion of legal pluralism (Griffiths, 1986). For example, the squat world was ruled by Punk Rock gangs in the Germany of early nineties. Squats in many East German towns were managed by Punk gangs without the intervention of the German state. The gangs ruled their anti-state ideology, procedures, norms and concepts (Ventsel, 2008).

The interaction among social groups is also a topic covered by legal pluralism since this is not static. Thus, legal pluralism should focus on the relations between nonState actors. Ehrlich and Moore ignored such fact and they regarded legal pluralism as something without motion. They just dealt with the influence of social norms into official law, brushing aside the influence of official rules on non-state rules and the influences "upon each other of the various non-state associations (Griffiths, 1986, p. 28)". Such omission would seem that it might be relevant in this era of globalization. It is evident that in our current society has emerged a myriad of non-state actors like Multinational companies without an apparent territorial linkage, the movement of assets and people or the enlargement of global communications, which allow the possibility to interact and have different options for legal authority towards the same action (Berman, 2013). Legal pluralism is therefore dynamic, "is one in which law and legal institutions are not subsumable within one 'system' but have their sources in the self-regulatory activities of all the multifarious social fields present (...) (Griffiths, 1986, p. 39)". This was the strong, deep, sociological or new legal pluralism defended by Griffiths.

On the other hand, there is the weak, classical or juristic legal pluralism which is when the State recognizes or approves others legal frameworks from different society groups (Jackson, 2005). This means the incorporation of private regulation, customary law or any other type of sub-state regimes into the State law regime (Jackson, 2005).

Notwithstanding the different colors into the broad concept of legal pluralism, this concept has definitely its common touchstones. One of them is that legal pluralists conceived the existence of other legal orders outside the State as a stark reality. Thus, all but legal pluralists support such idea, even though it seems elusive to delineate the boundaries between law and non-law (Tamanaha, 1993). 
Another important touchstone of legal pluralism is that law and society are inseparable. If a society sprouts, so does the law. This was a cornerstone, which inspires the development of legal pluralism. Pospisil, Smith, Ehrlich, Moore, Griffiths and Vanderlinden, among others, recognize this as a strong argument for their theory. Thus, we might say that social structures trigger the effectiveness of the law.

Griffiths assured in his article that weak legal pluralism emerged as early as 1772 where the British Empire incorporated Hindu and Muslim law into family matters in India. Nonetheless, Griffiths' assumption was deemed misleading, since weak or strong legal pluralism had been a reality long time before the British colonialism in India (Menski, 2006,). Legal pluralism is not therefore just a question of colonialism or post-colonialism and as Griffiths claimed adamantly legal pluralism is a mere fact (Griffiths, 1986,), which might arise in all human societies (Menski, 2006).

Although Griffiths' concept of legal pluralism was found problematic and evidenced some conundrums, Griffith was right to determine that legal pluralism is a fact and recognized later that the law is a 'folk concept' that is, what people within their communities or groups label or see as a 'law'. Therefore, the law cannot be categorized into a scientific pattern, as people vary their perspectives about it over time and in different times (Tamanaha, 2008).

In times of globalization, new phenomena have encouraged the burgeoning popularity of legal pluralism among scholars. The late 20th and early 21st centuries have witnessed the infliction of global environmental damage, terrorism on a global scale, massive migration and the consumption on the Internet, among others. These real facts are all example of situations implying legal pluralism because the States have given up some sovereign powers to allow third or private parties take over economic, political or social affairs (Tamanaha, 2008). According to Tamanaha (2008), states are losing power. Many countries within the European Union have given up some economic and political powers to control their own issues. Furthermore, many private organizations promulgate their own rules to solve their disputes without the State and many other examples exist likewise.

It is therefore observed that the present context triggers the making of various types of official systems whose legal structures interact with other normative systems circulating within the society. It is considered adamant the recognition of such systems like trans-governmental networks, NGOs, sports organizations, electronic commerce transactions, supranational human rights courts, amongst others. Those interactions result in an inevitable "multitude of coexisting, competing and overlapping legal systems at many levels and in many contexts" (Tamanaha, 2008, p. 389). 
Environment protection has become one of those contexts that might rely upon legal pluralism as the vehicle of grappling with their issues. Due to the neoliberal discourse and a deep feeling of frustration, many social movements have participated within the United Nations Climate Change Framework (Dilwyn, 2015). Consequently, the 2010 United Nations Climate Change Conference in Cancun evinces how legal pluralism has already made its contributions to pursue issues related to environmental damage. This is the reason why some negotiating texts give the impression that plural approaches were taken seriously (Dilwyn, 2015). For example, the application of interlegality during this conference allowed the incorporation of different views of the problem into legal negotiations.

The concept of interlegality may be understood according to Pomade (2012) in two angles: 1) the passage of one legal system to another (how a non-legal norm becomes a legal one) and 2) the interactions of different legal systems and their actors, in other words, how scientific experts convince legislators with their arguments to draft legal norms based on their research works. Thus, interlegality implies the transfer of socalled no-legal binding rules into the strict legal order. In other words, a scientific, cultural, social or economic rule might become a full legal one due to the mechanism of interlegality. Of course, this process involves interactions and discussions followed by certain agreed rules, which result at the end with the drafting of a legal norm.

Under this perspective, the Cancun Conference allowed a legal pluralistic approach because of the application of interlegality. There were 9 different groups participating, however all of them were heard and included through the negotiations. Interlegality favoured the integration of different disciplines during the drafting of an environmental norm (Pomade, 2012). This is because interlegality proposes a system of interaction as the different points of views may have difficulties to reach consensus. During the Cancun conference, certain conflict of norms and also some difficulties with the jargon arose. Interlegality solves the problem of conflict as it establishes a clear set of rules and sets up criteria for actors involved and norms. In the Cancun conference, interlegality helped to set the rule of the respect of communication, the vulgarization and translation of all documents and the free concurrence among participants. The final decisions were based on the criteria already established for documents (neutrality, objectivity, understandability) and actors (preference for their performance in the arguments and vulnerability) (Pomade, 2012).

\section{THE ISSUES OF ENVIRONMENTAL HEALTH AND THE APPROACH OF POSITIVE LAW}

A great pioneer of environmental health was Rachel Carson. She published the book Silent Spring in 1962, which contributed to the ban of DDT -dychloro diphenyl trichloroethane-in the US. Carson achieved the shift of public discourse about the environ- 
ment and its role in enhancing human health (Dunn, 2012). Her movement spurred international community in its first attempt to address environmental issues for human health: The United Nations Convention on the Human Health, held in Stockholm in 1972. Likewise, Silent Spring triggered the Brundtland Report, also known as Our Common Future, in 1987, which brought into the world the concept of sustainable development. This was later materialized with the Declaration of Sustainable Development of Agenda 21 in the 1992 Earth Summit celebrated in Rio de Janeiro.

In spite of the advances made with Agenda 21, cardiovascular diseases, obesity, diabetes, cancer, respiratory diseases, neurological diseases, and reproduction problems continue their escalation within our society. Policies are furthermore still on the same approach, which is to take no heed of environmental dimension in health. However, the scientific community has recently achieved to prove the linkage between these diseases and the environment. In other words, environmental issues such as air or water contamination, low-quality work, habitat conditions, low-quality alimentation and lifestyle have sheer influence over these diseases. These illnesses affect developed and developing countries likewise (Cicolella, 2013).

According to the World Health Organization (hereinafter WHO) previsions, there will be 52 million deaths by 2030 for non-transmissible diseases (88\%), whereas contagious or infectious diseases will amount to $12 \%$ of deaths. This means that while progress has been made against AIDS, tuberculosis or malaria, the world is experiencing a real epidemic of non-contagious diseases (WHO, 2011).

The economic consequences of such problem were presented in an economic report by Harvard University School of Public Health at the World Economic Forum. According to this report, people suffering non-communicable diseases are usually absent from their jobs, lose them or even take anticipated retirement, fostering poverty. The report concluded that non-communicable diseases remain as one of the threats for global economic development (Cicolella, 2013, p. 15). Chronic diseases become an excellent example thereof, since environmental factors have proven to influence their rise. John Higginson explained the environment as $80 \%$ cause of cancer. Although Doll and Peto debunked him, revelations made in 2006 put the binary environment-cancer again on the table. For example, the National Academy of Medicine in France declared that endocrinal disruptors such as Bisphenol A might be carcinogenic. A study based on twins achieved to demonstrate that two cancers of three are related to the environment. In fact, causes related to the environment on the three main cancers are quite high: $73 \%$ breast cancer, 58\% prostate cancer, and 65\% bowel cancer. Environmental factors seem also to be related to the increase of cancer in children and teenagers (Cicolella, 2013). There are also environmental factors attributed to asthma, mental illnesses like Alzheimer disease (AD), tuberculosis, pneumonia, Minamata disease, SARS, 
Ebola, Chikungunya virus, measles and others. Many cases originate from human actions and not solely from natural or genetic reasons (Gauthier-Clerc $\&$ Thomas, 2010).

Nevertheless, what is positive law doing to dealing with environmental health? International law has proven no clear success in precluding environmental damage to human health. Some of the most relevant treaties that tackle questions regarding environmental health are the Stockholm Declaration in 1972, the Rio Declaration in 1992, the Aarhus Convention in 1998, and the Stockholm Convention on Persistent Organic Pollutants in 2001.

Although those treaties might have inconveniences in enforcement, they have paved the way to draw attention on environmental health. Montreal Protocol and Kyoto Protocol could be examples of environmental multilateral agreements that have succeeded insofar as promoting health and compliance (Von Schirding, Onzivu \& Adede, 2002). On that account, we might say that international positive law has contributed to galvanize action and create political awareness locally and around the globe, despite the weak enforcement and dwindling monitoring mechanisms (Von Schirding, Onzivu E Adede, 2002).

Montreal Protocol on substances that deplete the ozone layer boasts wide recognition for its achievements; one of the key reasons that explain why it could have achieved their goals lies in its interdisciplinary approach. Several distinct groups like regional or national networks, scientists, economists, IT workers, technicians and others, participate in its enforcement (Rae \& Gabriel, 2012). Accordingly, the Montreal Protocol resulted in a compliance rate of over 98\% (Ozone Secretariat, 2015).

Albeit the Montreal Protocol has succeeded, similar environmental treaties have not encountered the same reality. In general terms, the appraisal for the international environmental law framework confirms that the international positive law does not acknowledge the right of a healthy environment with a particular status (Maguire, Lewis \& Sampford, 2013). Other authors discuss that the incorporation of such right within national Constitutions might catalyze a higher environment protection and decisions for environmental health (Boyd, 2012).

According to May quoted in Maguire, Lewis \& Sampford (2013),, constitutional recognition to environmental health does not seem to promote enforceability. As it is suggested by May in Maguire, Lewis \& Sampford (2013),

national courts are reluctant to uphold fundamental environmental rights as self-executing and enforceable. Many such rights have yet to be tested in national 
courts, and (...) that of those that have been tested, around half of them have been found to be enforceable. (p. 199)

Despite the fact that positive law has succeeded to set up a network of procedures and principles for environmental health issues, the challenges for enforceability remain. Enforcement has been difficult to accomplish, even though environmental rights hold constitutional protection, because of the behavioural component of the actors or regulators involved. On one hand, local protectionism often emerges in cases of environmental damage, and on the other hand, difficulties in obtaining remedies or the procedures for enforcement are regularly postponed or too ambiguous (Von Schirding, Onzivu \& Adede, 2002). In other words, "(...) constitutional environmental provisions can only be as effective as the laws which give them detail and the courts which enforce them (Maguire, Lewis \& Sampford, 2013, p. 200)".

Brazilian Constitution exemplifies this argument as it has enshrined the right to an ecologically balanced environment, stating that "everyone has the right to an ecologically balanced environment, which is a public good for the people's use, and is essential for a healthy life (Maguire, Lewis \& Sampford, 2013, p. 200)". Nevertheless, it seems that such right will be difficult to enforce, taking into account the sheer reliance on Brazilian Economy in timber and agricultural industries. Also, this Constitutional right is so broad that in practice it has been quite difficult to implement. Similar examples are found in the constitutions of other developing countries such as Togo, Republic Democratic of Congo, Chile, Ecuador, Argentina, Ethiopia and Angola. The majority of those countries link protection for the environment with human development or health. However, every country has encountered its own reasons for weak enforcement, resulting in the continuity of environmental diseases (Maguire, Lewis $\mathcal{E}$ Sampford, 2013).

In many cases, media attention and NGOs pressure become a successful tool to enforce environmental laws and policies. Agenda 21 has determined the role of NGOs regarding the pursuit of environmental rights and its enforcement. The influence of NGOs on the global environmental agenda is burgeoning as well as their massive intervention in environmental enforcement. NGOs and their coalitions have contributed to implementing, codifying, and even enforcing environmental policies around the world (Maguire, Lewis \& Sampford, 2013). Furthermore, NGOs are able to mobilize public through campaigns and social media.

Under this perspective, the positive law has only remained to establish the framework, the boundaries, the procedures and the sanctions, but it has not been able to bond networks. Also, it seems that for many countries environmental health is not deemed as a strong legal binding principle: 
The fact that so few states have formulated their constitutional environmental rights in terms, which make them judicially enforceable, suggests states may not view the right to a good environment with the necessary opinio juris to render it a rule of customary international law. Rather, it may indicate that most states view the right as aspirational or idealistic in nature - something which is important to recognise in the constitution but which creates little in the way of binding legal consequences. (Maguire, Lewis \& Sampford, 2013, p. 200)

Notwithstanding such an argument, international tribunals have balanced the power in favor of the environment on several opportunities. Thus, environmental rights have been obtained, as fundamental rights. In Turkey, the European Court of Human Rights recognized on the case Okyay and Others vs. Turkey, the right to live in a healthy environment as constitutional, despite of the many problems with enforcement (Harrison, 2006).

Furthermore, the access to justice is one of three pillars of the environmental rule of law (Pring y Pring, 2016). Therefore, the essential role of environmental courts towards the enforcement of environmental health is undeniable.

\section{DEALING WITH ENVIRONMENTAL HEALTH ISSUES: POSITIVISM VERSUS LEGAL PLURALISM}

In a nutshell, the positivist theory of law outlined the following tenets: The law is the one and the only object of the law; what is not deemed as law it is not considered worthy to be studied as a part of the law; the validity of a norm stems from another one which is superior; the norms are obeyed or infringed in terms of what law has established; values are considered absolute as long as those were designated as such by norms; in other words the law is not a mere fact, the law must be always validated with another law (Kelsen, 1962).

Such tenets lead to the restricted criteria of the laws and nothing else. The source of our critics for the positivist theory is what the law has been recently doing. This research exercise raises a list of some characteristics in order to justify the setbacks of positivist theory against legal pluralism in dealing with environment health. The list is neither exhaustive nor incomplete, however, it might be regarded as criteria grid to orientate a switch proposal to tackle environmental health issues and its legal challenges for the future.

\subsection{Positivist Approach for Environment is Hierarchical; Legal Pluralism Acknowledges a no-hierarchical Multiplicity of Systems}

Constitutional norms, federal, national, provincial or statutory laws validate the quality, effectiveness, performance, scope or interpretation of a law; if they don't do so, the 
Supreme Courts do so through jurisprudence. This is the world of positivist theory and its hierarchy.

As an illustration, we found examples of Environment Policy in Germany -the Trianel Case (Case C-115/09)-and the United States which demonstrate the dynamics of power in Environmental law. According to Weidner (1997),

In the case of Germany, for instance, ambivalent effects can be pointed out, which arise when general participatory deficits in environmental politics are compensated for through a strengthening of the legal positions of individuals and environmental organisations (...) this could, especially as the position of the administrative courts is thereby strengthened, trigger a further slide into simple reliance on litigation (...) which could make the system, already over regulated, still less flexible. It is evident from the example of the USA that an extension of the general right of citizens to participate in environmental decision-making can lead to an intensification of conflicts and the blocking of vitally necessary environmental policy decisions. Furthermore, it can lead to endless courtroom battles and impenetrable barriers to investment projects, triggering a backlash as soon as a change in the general environmental policy framework conditions grants economic actors and their political supporters a more favourable position in the power structure. (p. 21)

American law has in the judiciary the responsibilities of the interpretation of laws, according to Constitutional and Common Law standards, but along with the grip of the legislative branch that creates the law. Any environmental complaint triggered the same dynamic. All statutory law must be in accordance with the Constitution, but the statutory law is likewise superior to the regulatory one (McGuire, 2014).

Positivist mindset predicts a unilinear path to deal with environmental health issues. The environmental law is interpreted according to constitutional and statutory standards. Therefore, the executive branch applies the law by taking into account the Court's decisions. However, such dynamic often ignores the multidisciplinarity and the plurality endowed with environmental health. Techera (2010) mentioned that "in general it could be said that state-based dominant legal systems have tended to marginalise customary law and in many cases continue to do so. Rather than support each other, these laws are often in conflict (...)" (p. 8).

Having a hierarchical system leads to a strict process of verification. However, does validation have a leverage towards the accomplishment of the purpose of a law? Instead, legal pluralism offers an open discussion of the issue where the validity of the law is not a concern. As it was proposed by McGuire (2014), "the legal doctrines become both the foundation and, often, the outer limit by which environmental problems are viewed. When issues are considered under theses constraints, the result is often an attempt to redefine the problem within legal parametres" (p. 4). 
Legal pluralism welcomes interlegality where boundaries of the hierarchy are usually blurred, and flexibility appears as the only rule within the decision-making process in dealing with environmental issues. A stark example to argue such point is the marine conservation in the Asia Pacific: Native communities in Oceania held the right to fish, which was controlled by one clan chief or one family. This determined the tenure of reef and lagoon and how to distribute the harvest (Johannes, 1978).

Traditions in the Asia Pacific have managed marine conservation through coordination of different groups of people who lived in the area for many years, and whose approach has been to limit access in marine areas (Johannes, 1978). Of course, the success of this approach in dealing with the environment is highly arguable: There is no guarantee that this manner of conservation would prevent an environmental depletion.

Nevertheless, we can argue that the use of interlegality might be more helpful instead of relying on an approach of exclusive state governance. We insist that positive law encourages a unique way of hierarchy. Clans or tribes in the Asia Pacific and Oceania have also hierarchies, but not always in a unilinear way. In Palau, they have the traditional millenarian practice of Bul: It "involves a Council of Chiefs placing reefs areas off limits to fishing during spawning and feeding (Idechong, n. d., p. 1)". This Bul has become a full binding set of rules through the Palauan Protected Area Network (PAN) law. However, Palauans combined such approach with the government and the communities through the Council of Chiefs. The Council communicates directly with the President of Palau to declare offshore sanctuaries. They work in tandem and thereby they do not have to wait for a legal decision on the matter. They share authority and consensus (Gruby, Campbell, Fairbanks $\mathcal{E}$ Gray, 2017). This is interlegality in the making.

Although many countries include in their constitutions a right of participation for environmental issues, some setbacks still prevail. Colombia, as an example, achieved much advancement in pluralist participation; however, the grip of the centralist approach remains. Accordingly, despite the creation of the Intersectorial Council for Envrionmental Health -Conasa- and the integration with Territorial entities, the lack of coordination among NGOs, communities, local governments and private sector continues (Rodríguez, 2014). Conasa holds an advisory role and its decisions are not binding (Departamento Nacional de Planeación, 2008). This is probably because a process of interlegality is still pending.

\subsection{Positivism Depends on Theoretical Rules to Solve Environmental Problems, Whereas Legal Pluralism Promotes Pragmatism to Tackle Issues}

The history of law as a field of study entails a profound attachment to legal practice. The study and research of the law stem only from what the State creates. Legal positivists, 
especially doctrinal researchers, believe that the mere data for the law are legislation and cases (Vick, 2004). They conceive the law "from no more than a thorough examination of a finite and relatively fixed universe of authoritative texts consisting of cases, statutes, and other primary sources" (Vick, 2004).

The positivist theory observes an exclusive concern of the analysis of statutes, core principles or authority cases. A strict environment positivist approach preoccupies with the search for a golden rule to tackle the problems or environmental dilemmas that might (Hull, 2008). Positivism operates through a sealed system to resolve environmental issues, which relinquishes outside criteria.

However, no intent is being made to claim that environmental international treaties and its positive approach are meaningless. On the contrary, examples like the Montreal Protocol proved how the international environmental law might achieve commitment from governments and with high degrees of enforceability. The argument is that validity and conformity with the law by itself does not achieve the purpose of relieving the environment and improving the lives of people. This is the example of the article $8 \mathrm{j}$ of the Convention on Biological Diversity (hereinafter $\mathrm{CBD}$ ), which is deemed to be too broad and ambiguous, or with difficulties for the validity of the law.

The Courts might reject and oblige a polluter to comply with the law, but the reality establishes that the mere act to stop the wrongdoing seems not enough to finish or deal with the problem. Monitoring, community involvement and a change of business models are needed to achieve what positive law could scarcely obtain. For a strict positive lawyer, the fact that a government complies with standards established in environmental law is enough to fulfill commitments. However, for natural scientists, or an environmental activist, the law itself seems to be innocuous (Koivurova, 2014).

In the matter of the CBD Article 8j, concerning indigenous rights to protect traditional knowledge, it is found that an extra working group to pursue and follow up implementations can become a supportive mechanism for enforcement.

The development of Article $8 \mathrm{j}(\ldots)$ is a good example of the gradual development process of international environmental regimes in practice: even vague provisions can be given substantive content (...) with the collaboration of other actors, such as indigenous representatives, thereby helping national civil servants devise measures. (Koivurova, 2014, p. 18)

Other examples in which positive law found difficult to achieve its objectives are found in the Kyoto Protocol. It is said that the simple prohibition of a $5 \%$ reduction in 
greenhouse gas emissions "would not be sufficient to stop global warming and prevent climate change (Koivurova, 2014, p. 22)".

On the other hand, environmental legal pluralism promotes pragmatism, encouraging spaces for deliberation. Thus, the depth and soundness of arguments weigh against a rigid or biased voting process. In the words of Hull (2008), "Environmental pluralism assists environmental decision making by helping to identify the values -and trade-offs- that are being negotiated (p. 385)". Pluralism allows all actors involved in an environmental issue to collaborate with no hierarchies and no impositions over other ideas of a principle, which hides a particular interest or biased opinion. The decisions will come from negotiated solutions that will be tested in real management situations. Hence, pluralism requires negotiators being capable of accepting legitimacy in other's arguments, a high level of collaboration and willingness to share information (Hull, 2008).

Within this context, local networks become essential for the development of pluralism in environmental health. Legal pluralism would allow those small communities might outline their own set of rules that will be accomplished for the rest of actors. The set of norms what it can be dubbed as 'law' will be also flexible, an important feature of adaptation in the changing situation of the environment. Examples of this are well documented with the Sàmi in Scandinavia as they grasped the process of grazing distribution for reindeer according to the behaviour of the animal and the environment (Ahrén, 2004). All Scandinavian countries have incorporated Sàmi Parliaments elected by and among the Sàmi (Richardson, 2008).

The pragmatism implied in legal pluralism welcomes likewise deliberative democracy, whose most efficient tool has been interlegality. The latter allows a dialogue among different norms and actors from distinct disciplines. Thus, decisions are not exclusive legal ones. Rather, they might result from the interaction among plural actors without hierarchies. The Cancun Climate Change Conference in 2010 was an example because, in using interlegality, plural actors could have reached consensus on complex and different issues. Some criteria applied through the meetings were the obligation for all participants to respect the others' interventions, and also the capacity to defend arguments was more privileged than superior norms or bargaining power (Pomade, 2012).

\section{A POSITIVE CONCEPT OF SOVEREIGNTY AN OBSTACLE FOR REGULATING ENVIRONMENTAL HEALTH VS. A FLEXIBLE CONCEPTION FAVORED BY LEGAL PLURALISTS}

Positive law has established, through International Law, the concept of sovereignty as a part of the 'rule of law' and the utmost right for each member of the international 
community of States. Although the concept of sovereignty might be regarded as broad and quite complex, it remains the most reverenced notion by the international law. The concept of sovereignty is a notion conceived in the relations amongst States (Bal, 2012). Also, State sovereignty is deemed as a "competence, immunity, or power, and in particular as the power to make autonomous choices (Besson, 2011, p. 376)". Hence, sovereignty implies that governments keep supreme power to control their own territory in providing and enforcing laws (Wijsman, n. d.).

Of course, environmental policies and laws stay under the concept of State Sovereignty. According to Principle 21 of the Stockholm Declaration of 1973, "States have (...), the sovereign right to exploit their own resources pursuant to their own environmental policies, and the responsibility to ensure that activities within their jurisdiction or control do not cause damage to the environment of other States (....." In broad terms, State sovereignty as established by positive law fosters the impossibility to deal with complex and coordinated issues of environmental health. Complex issues like air pollution, asbestos contamination, and the decline of biodiversity, are seldom shared with either other states or local communities.

The Bophal disaster in India that killed more than 3800 people due to a toxic gas leakage evinced that an exclusive control from the government over environmental standards bring crippling effects. In words of Broughton (2005), "the local government was aware of safety problems but was reticent to place heavy industrial safety and pollution control burdens on the struggling industry because it feared the economic effects of the loss of such a large employee.(p.2)". The Supreme Court of India ruled the case with no great consequences for the Union Carbide Company-UCC- that paid US\$ 470 million, which is a relatively small amount.

The Bophal case, as well as the Minamata disease, pictured the simple fact that hard law has included environmental regulations would not be enough to attain improvements. Indeed, positive law hesitates to join non-state actors into negotiations for regulation, and it also protects vigorously a western economic model that privileges capital interests from private investors. Moreover, State Sovereignty minimizes other actors' role into environmental health -such as NGOs, Transnational Corporations, local communities, indigenous peoples or environmental activists-, undermining their real expertise and experience with the environment and social context. Taking into account such predicament, how can State Sovereignty be more dynamic? Is it possible that State Sovereignty might be relaxed in terms of the environment to tackle public health issues? The answer might be found in the tenets of Legal Pluralism.

Positive law has attempted to give non-State actors like indigenous people a certain level of Sovereignty. However, the recognition of positive law in indigenous 
rights remains very restricted, as the State holds sway in the regulation of Indigenous peoples' lives and the acknowledgement of customary law (Techera, 2010). In spite of the progress through the ILo Convention 169 Concerning Indigenous and Tribal Peoples in Independent Countries (ILO169), some other issues are still in need of the full level of self-determination among of them, for example, environmental health (Techera, 2010). Some other international environmental law instruments have tried to reconcile positive law with legal pluralism such as the Convention on Biodiversity or the ILO 169; however, there have been missed opportunities to allow that legal pluralism might be the bridge between "hard" and "soft" law.

Legal pluralism favors the possibility to relax the concept of State Sovereignty. According to Teubner (1991), legal pluralism is enshrined into the mechanisms of transnational legal systems and organizations that curtail and transform current powers and the constitutional sovereignty. The former implies that State Sovereignty is not a static concept. Rather, State Sovereignty evolves according to the situation and social context, confirming one of the tenets of Legal pluralism: Law and society are inseparable. This concept of a non-static State Sovereignty is crucial for environmental issues, because it fosters the adaptability to changes. State Sovereignty will no longer be a rigid concept that depends on State Law to proceed. On the contrary, State Sovereignty will be delegated to other actors so as to apply, create or orientate regulations, frameworks and decision-making processes.

In practice, the role of non-States actors in dealing with environmental issues is undeniable. The insights of Teubner (2012) set in motion the dynamic process of nonstate actors pursuing any sort of social agendas. A clear example of this evolution or relaxation of State Sovereignty is found in Transnational Corporate Codes of Conduct:

The Codes reveal an inversion of the hierarchy between state law and private ordering. This reversal is striking in the hard law/soft law dimension. State rules are now only 'soft law', while the mere private ordering of transnational corporations has gained in strength to become 'hard law'. (Teubner, 2012, p. 48)

It seems adamant to claim that, for example, the UN Codes of Conduct were supposed to be "binding norms"; however, due to resistance from influential nation-States, the version ended to become a non-binding soft-law bunch of recommendations. On the other hand, international company codes according to Teubner (2012) are an example of non-state ordering that is enforceable and widely binding, accompanied with sanctionatory powers.

The argument of Teubner leaves the assertion that internal organizational or Corporative Codes of Conduct do not depend on State regulations or Constitutional 
Sovereignty to pursue the provided regulations and their enforcement. Those codes do not search their validity from the primary or secondary sources of the legal domain (Teubner, 2012). This insight gives a clue to constitute an example of how legal pluralism in relaxing Sovereignty might contribute to deal with environmental health issues. This is the example of the burgeoning power of Environmental Corporative Social Responsibility. This possibility of Codes of Conducts entails legal pluralism, which also comes with a kind of discussion. Since Codes of conduct issues are based on legal pluralism, private companies are highly prone to privilege their own interests (Rahim, 2013) and thereby undermining general environmental welfare.

Notwithstanding the discrepancies of Corporative Social Responsibility, many non-state organizations have taken an active role in protecting the environment. They know that they are replacing the role of a State, whenever this has been absent or ineffective. These environmental organizations "have taken a lead role in developing a number of international voluntary certification regimes that apply to the cSR area (Institute of Medicine, 2007, p. 85)". For example, the Forest Stewardship Council initiative, the OECD (Organization for Economic Corporation and Development) Guidelines for Multinational companies, or the International Standard Organization (ISO), evince the success of Corporative Social Responsibility in dealing with the environment. In brief, NGOs have developed different voluntary codes as supplements of positive law so as to offset some of its drawbacks. NGOs have discovered that they are not mere rule takers; they can also take initiatives to issue policies. Non-state organizations can also have allies in the retail sector or with other business actors to control enforcement tracking with retailers who do not comply with the standards (Institute of Medicine, 2007). Legal pluralism, therefore, permeabilizes small networks and the interconnectedness existing in today business and social practices.

\section{CONCLUSIONS}

The sheer scientific literature has evidenced the pitfalls of environmental damage in human health. Researchers agreed that environmental damage might be linked to chronic and epidemic diseases around the world. The impacts of positive law in addressing this issue are twofold: It has created global awareness, but it is also found with dwindling monitoring mechanisms.

Positive law has won some victories for the environment, such as the implementation of the Montreal Protocol on substances. Nevertheless, there are still issues regarding environmental health pending for a solution. Positive law has protected the right to healthy environment up to a constitutional level. This constitutional protection, however, seems not enough to achieve enforcement. National jurisdictions are not fully engaged with environmental issues: They usually recognized them, but binding 
measures do not exist. Rather, national economic interests are privileged, especially in developing countries.

This weakness of positive law regarding environmental health encourages legal pluralism. Legal pluralism strengthens the participation of local communities and NGOs in the environmental health issue. This theory could resist against economic hegemony and ubiquitous influence from national governments.

This is because positive law does not allow a broken hierarchy. State law tends to favor power relations, since it is the sole authority that makes decisions. Such predicament curtails the possibility to get out of the vicious circle of court litigation. On the contrary, legal pluralism opens the opportunity to deal with environmental issues in a more flexible unfettered way. Many examples in local native communities have demonstrated to give enhanced results for the environment. Legal pluralism offers the possibility to discuss and change conditions without judicial constraints or along with the evolution of the situation.

Moreover, positive law relies on theoretical rules mainly. Although this promotes commitment by the governments, it does not accomplish meaningful protection in environmental health. In other words, the mere fact of keeping with the rules is not a guarantee of suitable protection for the environment. Positive law needs therefore the support of local communities or other private actors to succeed. In contrast, legal pluralism encourages deliberation. The use of interlegality allows the application of legal pluralism in environmental matters. For example, the Sàmi have solved many land tenure issues with deliberation and interlegality. They privileged consensus and sacrificed bargaining power to reach a general decision. Also, international environmental conferences have seen interlegality as a useful tool, since it allows an interdisciplinary approach to emerge. Positive law has little room for interdisciplinarity, and it is probably more satisfied with the mere validation of theoretical rules.

Legal pluralism offers the possibility to relax state sovereignty in dealing with environmental health issues. The positive law in environmental damage cases has diminished the role of non-state actors to contribute and thereby relinquishing possibilities of new alternatives. However, some independent actions have been arisen by international companies. Those companies have produced corporative codes of conducts that regulate in somehow environmental issues. There are also some NGOs that have replaced the role of the State. Such organizations take the advantage to liaise with small networks so as to reinforce environmental standards within an industry. This might be done without the consultation of State law. 
Notwithstanding what it has mentioned, this is a theoretical justification for further research purposes. This means that, in practice, many challenges might arise. To what extent is it convenient to leave full control of environmental decisions to non-state actors? To what extent legal pluralism can privilege democracy and brush aside private interests? Are all environmental health issues suitable to a legal pluralist approach? It seems that an ongoing field research might yield new insights.

\section{REFERENCES}

Ahrén, M. (2004). Indigenous People's culture, customs, and Traditions and Customary Law- The Saami People's Perspective. Arizona Journal of International \& Comparative Law 21(1), 63-112.

Bal, L. (2012). Le Myhte de la souveraineté en Droit International. La souverainetédes États à l'Épreuve des mutations de l'ordre juridique international. (tesis de doctorado). Strasbourg, France: University of Strasbourg.

Berman, P. S. (2013). Le nouveau pluralisme juridique. Revue internationale de droit économique, XXVII(1), 229-256. doi: 10.3917/ride.259.0229

Besson, S. (2011). Sovereignty, International Law and Democracy. The European Journal of International Law, 22(2), 373-387.

Boyd, D. (2012). The right to a Healthy Environment. Revitalizing Canada's Constitution. Vancouver: UBC Press. Retrieved from https://www.ubcpress.ca/asset/9095/1/9780774824125.pdf

Broughton, E. (2005). The Bhopal disaster and its aftermath: a review. Environmental Health, 4(6), 1-6. doi:10.1186/1476-069X-4-6

Hull R. B. (2008). Environmental Pluralism. En Callicot, J. B. y Frodeman, R. (Eds.), Encyclopedia of Environmental Ehtics and Philosophy (pp. 384 387). United States: Macmillan Reference, Gale Cengage Learning.

Cicolella, A. (2013). Toxique Planète: Le scandale invisible des maladies chroniques. Paris, France: Éditions du Seuil.

Departamento Nacional de Planeación (2008). Documento Conpes 3550. Lineamientos para la formulación de la política integral de salud ambiental con énfasis en los componentes de aire, calidad de agua y seguridad química. Retrieved from: http://www.minambiente.gov.co.

Dilwyn, A. (2015). Legal pluralism and Human Rights in the idea of Climate Justice. Oslo Law Review, (3), 200-224. doi: http://dx.doi.org/10.5617/oslaw2766

Dunn, R. (2012). In retrospect: Silent Spring. Nature 485, 578-579. doi: 10.1038/485578a

Gauthier-Clerc, M. E Thomas, F. (2010). Écologie de la Santé et biodiversité. Brussels: Éditions De Boeck.

Gawel, A. (2017). Pollution is a silent killer. Here's how we can stop it. Geneva: World Economic Forum. Retrieved from: https://www.weforum.org/agenda/2017/11/pollution-how-to-stop-the-silent-killer/. 
Gruby R, Campbell L, Fairbanks L y Gray N. (2017). To succeed, Large Ocean Sanctuaries Need to Benefit Both Sea Life and People. Santa Cruz, California, United States: Island Conservation. Retrieved from: https://www.islandconservation.org/ocean-sanctuaries-benefit-palau-people/

Griffiths, J. (1986). What is Legal Pluralism? The Journal of Legal Pluralism and Unofficial Law, 18 (24). 1-55. doi: 10.1080/07329113.1986.10756387

Harrison, J. (2006). Significant International Environmental Law Cases. Journal of Environmental Law, 18 (3), 505-516.

Hertogh, M. (2007). What is Non-State Law? Mapping the Other Hemisphere of the Legal World. doi: $10.2139 /$ ssrn. 1008451

Hsiao, E. (2012). Whanganui River Agreement -Indigenous Right and Rights of Nature-. Environmental Policy and Law 42(6), 371-375.

Idechong, N. (n. d.). Micronesian Sea Traditions-Palau's Marine Protected Areas. United States: United Nations. Retrieved from: http://www.un.org/Depts/los/consultative_process/documents/7abstract idechong.pdf

Institute of Medicine. (2007). Global Environmental Health in the 21st Century: From Governmental Regulation to Corporate Social Responsibility: Workshop Summary. doi: https://doi.org/10.17226/11833.

Jackson, S. (2005). Legal pluralism and the Nation State: Romantic Medievalism or Pragmatic Modernity. Fordham International Law Journal, 30(1), 158-176.

Johannes, R. E. (1978). Traditional Marine Conservation Methods in Oceania and their Demise. Annual Review of Ecology and Systematics. 9, 349-364.

Kelsen, H. (1962) Théorie pure du droit. Traduction française de la $2^{2}$ édition de la «Reine Rechtslehre» par Charles Eisenmann. Paris: Dalloz.

Koivurova, T. (2014) Introduction to international environmental law. New York: Routledge.

Kothari, A., Margil, M. E Bajpai, S. (2017). Now rivers have the same legal status as people, we must uphold their rights. London: The Guardian. Retrieved from: https://www.theguardian.com/global-developmentprofessionals-network/2017/apr/21/rivers-legal-human-rights-ganges-whanganui

Landringan P., Fuller R. Acosta N., Adeyi O., Arnold R., Basu N., ... Zhong M. (2018). The Lancet Commission on pollution and health. Lancet 2018, 391, 462-512. Retrieved from: https://www. thelancet.com/pdfs/journals/lancet/PIIS0140-6736(17)32345-0.pdf.

Maguire, R., Lewis, B. E Sampford, C. (2013). Shifting global powers and International Law. Challenges and Opportunities. London and New York: Routledge.

Mc Arthur, J. (2013). International Environmental Law: Can it overcome its Weaknesses to Create an Effective Remedy for Global Warming? Santa Clara Journal of International Law, 10(2), 253-282.

McGuire, Ch. J. (2014). Environmental Law from the Policy Perspective: Understanding How Legal Frameworks Influence Environmental Problem Solving. Boca Raton, United States: CRC Press. 
Merry, S. E. (1988). Legal Pluralism. Law E Society Review, 22(5), 869-896.

Menski, W. (2006). Comparative law in a global context: the legal systems of Asia and Africa. Cambridge, UK: Cambridge University Press.

Moeller, D.W. (2011). Environmental Health. Cambridge, United States: Harvard University Press.

Mol, A. P. J. (2016). The environment nation state in decline. Environmental Politics, 25 (1), 48-68. doi : 10.1080/09644016.2015.1074385

Morrison, D. E Tyree, C. (2017). Invisibles. El plástico dentro de nosotros. Washington: Orb Media. Retrieved from: https://orbmedia.org/stories/El_pl\%C3\%Alstico/data

Ozone Secretariat, (2015). Montreal Protocol- Achievements to date and challenges ahead. Nairobi, Kenya: UNEP. Retrieved from: http://42functions.net/en/MP_achievements_challenges.php.

Perez, O. (2004). Ecological sensitivity and global legal pluralism. Rethinking the Trade and Environment Conflict. Oxford and Portland: Hart Publishing.

Pomade, A. (2012). Penser l'interdisciplinarité par l'internormativité. Illustration en droit de l'environnement. Revue Interdisciplinaire d'études juridiques, 68 (1), 85-106.

Pring, G. E Pring, K. (2016). Environmental Courts E Tribunals: A guide for policy makers. United States: Environmental Law Alliance Worldwide. Retrieved from: https://www.elaw.org/environmentalcourts-tribunals-guide-policy-makers-unep

Rae, I. E Gabriel, A. (2012). Saving the ozone layer: why the Montreal Protocol worked. Melbourne, Australia. The Conversation. Retrieved from: https://theconversation.com/saving-the-ozone-layer-why-themontreal-protocol-worked-9249

Rahim, M. (2013). Legal Regulation of Corporate Social Responsibility: A Meta- Regulation Approach of Law for Raising CSR in a Weak Economy. New York, United States: Springer.

Richardson, B. J. (2008). The Ties that Bind: Indigenous Peoples and Environmental Governance. Comparative Research in Law \& Political Economy, 4(5), 1-47. Retrieved from: http://digitalcommons. osgoode.yorku.ca/clpe/197

Rodríguez, G. A. (2014). El Sistema Nacional Ambiental quedó reducido a una utopía. La Silla Vacía. Retrieved from: https://lasillavacia.com/elblogueo/blog/el-sistema-nacional-ambiental-quedoreducido-una-utopia-47232

Rouland, N. (1994). Legal Anthropology. London: AEC Black.

Sievers, J. M. (2015). A Philosophical Reading of Legal Positivism. (tesis de doctorado). Lille: Université de Lille 3.

Tamanaha, B. (2008). Understanding Legal Pluralism: Past to Present, Local to Global. Sydney Law Review, 30(3), 374-411. 
Tamanaha, B. (1993). The folly of the "social scientific' concept of legal pluralism. Journal of Law and Society, 20(2), 192-217.

Taylor, A. L. (2008). International Law and Public Health Policy. In Heggenhougenand, K. E Quah, S. (Eds.), International Encyclopedia of Public Health, 3. (pp. 667-678). San Diego, United States: Academic Press. Retrieved from: http://oneill.law.georgetown.edu/media/2008_International-Law-and-PublicHealth-Policy.pdf

Techera, E. (2010). Legal Pluralism, Customary Law and Environmental Management: The Role of International Law for the South Pacific. Macquarie University Law School Legal Studies. Working Paper No. 2010-01. Retrieved from: https://papers.ssrn.com/sol3/papers.cfm?abstract_id=1545527.

Teubner, G. (2012). Constitutional fragments: Societal Constitutionalism and Globalization. doi: 10.1093/acpr of:Oso/9780199644674.001.0001.

Teubner, G. (1997). Global Bukowina: Legal Pluralism in the World Society. En Teubner, G. (Ed.) Global Law without a State. (pp. 3-28). Darmouth: Aldershot. Retrieved from: https://is.muni.cz/el/1422/ podzim2008/MP504Z/um/Bukowina_english.pdf.

Teubner, G. (1991). The Two Faces of Janus: Rethinking Legal Pluralism. Cardozo Law Review, 13, 1443-1462

Vanderlinden, J. (1989). Return to legal pluralism: Twenty years later. The Journal of Legal Pluralism and Unofficial Law, 21(28), 149-157.

Ventsel, A. (2008). Punx and Skins United: One Law for Us One Law for Them. The Journal of Legal Pluralism and Unofficial Law, 40 (57), 45-100. doi: 10.1080/07329113.2008.10756618

Vick, D. (2004). Interdisciplinarity and the Discipline of Law. Journal of Law and Society, 31 (2). 163-193.

Von Schirnding, Y., Onzivu, W. y Adede A. (2002). International environmental law and global public health. Bulletin of the World Health Organization, 80 (12), 970-974.

Weidner, H. (1997). Performance and Characteristics on German Environmental Policy. Overview and Expert Commentaries from 14 countries. Social Science Research Centre Berlin. Discussion Paper FS II 97-301. Retrieved from: https://bibliothek.wzb.eu/pdf/1997/ii97-301.pdf

World Health Organization. (2011). New WHO report : deaths form noncommunicable diseases on the rise, with developing hit hardest. New York. Retrieved from : http://www.who.int/mediacentre/news/ releases/2011/ncds_20110427/en/

Wijsman, K. (n.d.). State Sovereignty in a Time of global Environmental Problems: a Move towards Dynamism?" Retrieved from: https://www.academia.edu/14771977/State_Sovereignty_in_a_Time_of_Global_ Environmental_Problems_a_Move_towards_Dynamism. 